\section{Dentin Bond Strength of a Fluoride-Releasing Adhesive System Submitted to $\mathrm{pH}-$ Cycling}

Ana Rosa Costa ${ }^{1}$, Lourenço Correr-Sobrinho', Glaucia Maria Bovi Ambrosano ${ }^{2}$, Mario Alexandre Coelho Sinhoreti ${ }^{1}$, Gilberto Antonio Borges ${ }^{3}$, Jeffrey A. Platt ${ }^{4}$, Regina Maria Puppin-Rontani ${ }^{5}$

To evaluate the microtensile bond strength ( $\mu \mathrm{TBS}$ ) of a fluoride-containing adhesive system submitted to a $\mathrm{pH}$-cycling and storage time regimen for primary outcomes. As secondary outcomes the fluoride released amount was evaluated. Twelve dentin surfaces from sound third molar were divided into 2 groups according to adhesive systems: Clearfil SE Protect (PB) and Clearfil SE Bond (SE). Sticks obtained $(1.0 \mathrm{~mm} 2)$ from teeth were randomly divided into 3 subgroups according to storage regimen model: immediate (24h); 5 -month deionized water (W); and $\mathrm{pH}$-cycling model (C). All sticks were tested for $\mu$ TBS in a universal testing machine. Fluoride concentration was obtained from 1-4 days and 30-day in W and 1-4 days in demineralization (DE)/remineralization (RE) solutions from $C$, using a fluoride-specific electrode. $\mu$ TBS and fluoride released data were, respectively, submitted to ANOVA in a split plot design and Tukey, and Friedman' tests $(\alpha=0.05)$. There was no significant interaction between adhesive system and storage regimen for $\mu$ TBS. W showed the lowest $\mu$ TBS values. There was no significant difference between $24 \mathrm{~h}$ and $C$ models for $\mu$ TBS. There was no significant difference between adhesive systems. Failure mode was predominantly cohesive within composite for the $24 \mathrm{~h}$ and $\mathrm{W}$, for the $\mathrm{C}$ group it was mixed for SE and cohesive within composite for PB adhesive system. Fluoride concentrations in the DE/RE solutions were less than $0.03125 \mathrm{ppm}$ and not detected in W. In conclusion, the fluoride-containing adhesive system performed similarly to the regular one. Hydrolytic degradation is the main problem with both adhesive systems, regardless of fluoride contents.

\author{
'Department of Restorative Dentistry, \\ Dental Materials Division, Piracicaba \\ Dental School, UNICAMP - University \\ of Campinas, Piracicaba, SP, Brazil \\ ${ }^{2}$ Department of Community \\ Dentistry, Piracicaba Dental \\ School, UNICAMP - University of \\ Campinas, Piracicaba, SP, Brazil \\ ${ }^{3}$ Department of Dental Materials, \\ University of Uberaba, MG, Brazil \\ ${ }^{4}$ Department of Restorative Dentistry, \\ Indiana University School of \\ Dentistry, Indianapolis, IN, USA \\ ${ }^{5}$ Department of Pediatric \\ Dentistry, Piracicaba Dental \\ School, UNICAMP - University of \\ Campinas, Piracicaba, SP, Brazil
}

Correspondence: Regina Maria Puppin-Rontani, Avenida Limeira, 901, 13414-903 Piracicaba, SP, Brasil. Tel: +55-19-2106-5286. e-mail: rmpuppin@fop.unicamp.br

\section{Introduction}

The current trend of minimally invasive dentistry is to preserve as much as possible of the remaining tooth structure. In this conservative concept, composite restorations play an important role due to their adhesive ability. The main challenges that may compromise adhesive restorations are the marginal integrity loss and secondary caries. The latter is considered one of the main causes of restoration failure, with subsequent need for replacement and cumulative loss of tooth structure (1).

Fluoride has been incorporated into adhesive systems and composite resin to inhibit the development of secondary caries (2-4). Fluoride is known to have anticariogenic potential (5-9). Adhesive systems containing fluoride may inhibit cariogenic activity by increasing dentin resistance to acids present in the oral cavity and prevent secondary caries development by bonding and thus sealing dental tissues. However, da Silva et al. 2010 (10) showed that the fluoride-containing adhesive system did not interfere to decrease the severity of caries formation and seemed to demonstrate reliable bonding performance after 1 year of accelerated aging in water.

According to previous studies, a significant reduction in bond strength takes place after long periods in aqueous environments $(11,12)$. This reduction has been attributed to the absorption of water that affects the mechanical properties of the resin matrix material $(11,12)$, but the same acid challenge that induces cariogenic activity has also been suggested as a factor in the deterioration of the bonding performance (13). The fluoride that reduces demineralization and promotes remineralization in dental hard tissues may therefore also have a beneficial effect on the bonding properties of restorations (2-4,14-16).

The aim of this in vitro study was to evaluate the effect of a dynamic chemical challenge ( $\mathrm{pH}$-cycling model) and storage regimen on the degradation of the resin/dentinbond interface for two very similar adhesive systems, with and without fluoride. Bond strength was tested with 
microtensile bond strength ( $\mu \mathrm{TBS}$ ) and fluoride release was quantified as a secondary outcomes. The hypotheses tested were that there is (1) no significant difference in microtensile bond strength between the two adhesive systems, and (2) no significant difference between storage regimens.

\section{Material and Methods}

The experimental design was based on completely randomized design in sub-divided parcels so that the effect of adhesive system was allocated on the plots and the storage model in the subplots. Twelve extracted human molars (Fig. 1A) were used in this study according to protocols approved by the local Ethics in Research Committee. The teeth were stored in $0.1 \%$ thymol solution. The occlusal portion of the enamel was sectioned (Fig. 1B) with a water-cooled diamond blade (Isomet, Buehler Ltd., Lake Bluff, IL, USA), and mid-coronal dentin surfaces were wet-ground with 600-grit SiC paper (Carborundum Abrasivos Ltda, Recife PE, Brazil) to create a standardized smear layer.

The teeth were divided into 2 groups, according to the used adhesive system: Clearfil SE Bond (SE) self-etching adhesive system fluoride-free primer (Kuraray Co., Ltd., Umeda, Osaka, Japan) and Clearfil SE Protect (PB) selfetching adhesive system fluoride containing primer (Kuraray) (Fig 1C). Briefly the bonding procedures: adhesive system primer (SE or PB) was applied on the exposed dentin for $20 \mathrm{~s}$ and air dried; adhesive (SE or PB) was applied, dried using mild air flow and photo-activated for $10 \mathrm{~s}$ using a quartz-tungsten-halogen curing unit (XL2500, 3M
ESPE, St. Paul, MN, USA) with $700 \mathrm{~mW} / \mathrm{cm}^{2}$ determined using a power meter (Ophir Optronics Inc., Danvers, MA, USA). Three $2 \mathrm{~mm}$ increments of TPH composite (Dentsply Caulk, Milford, DE, USA) were applied to build up a block approximately $6 \mathrm{~mm}$ high. Each increment was photo activated for 40 s using the same curing unit. (Figs. 1 A-D)

After $24 \mathrm{~h}$ storage in deionized water at $37{ }^{\circ} \mathrm{C}$, the specimens were sectioned perpendicular to the bonding area to obtain sticks with a cross-sectional area of $\sim 1$ $\mathrm{mm}^{2}$, using a water-cooled diamond blade (Figs. 1E, 1F). The most peripheral area sticks presenting residual enamel were excluded from the test. Sticks from the same tooth of each adhesive system were mixed and then randomly divided into 3 subgroups according to storage time regimen (Fig 1F): immediate - control group (Fig 1G); 5 months in deionized water (Fig 1J); and, pH-cycling model (Fig 1K), comprising 6 experimental groups: PBI (Clearfill SE Protect + immediate test - control); PBC (Clearfill SE Protect + pHcycling model); PBW (Clearfill SE Protect +5 month water storage); SEI (Clearfill SE Bond + immediate - control); SEC (Clearfill SE Bond + pH-cycling model); and SEW (Clearfill SE Bond + 5 month water storage).

The sticks submitted to the $\mathrm{pH}$-cycling model (PBC and $\mathrm{SEC}$ ) and 5 month deionized water storage (PBW and SEW) were coated with an acid-resistant nail varnish, except for a $1 \mathrm{~mm}$ distance around the bonded interface area of the dentin/composite resin (Fig. 11). The specimens were submitted to four demineralization-remineralization cycles at $37^{\circ} \mathrm{C}$. Each cycle consisted of $4 \mathrm{~h}$ periods of immersion in demineralization (DE) solution followed by $20 \mathrm{~h}$ periods of immersion in remineralization (RE)

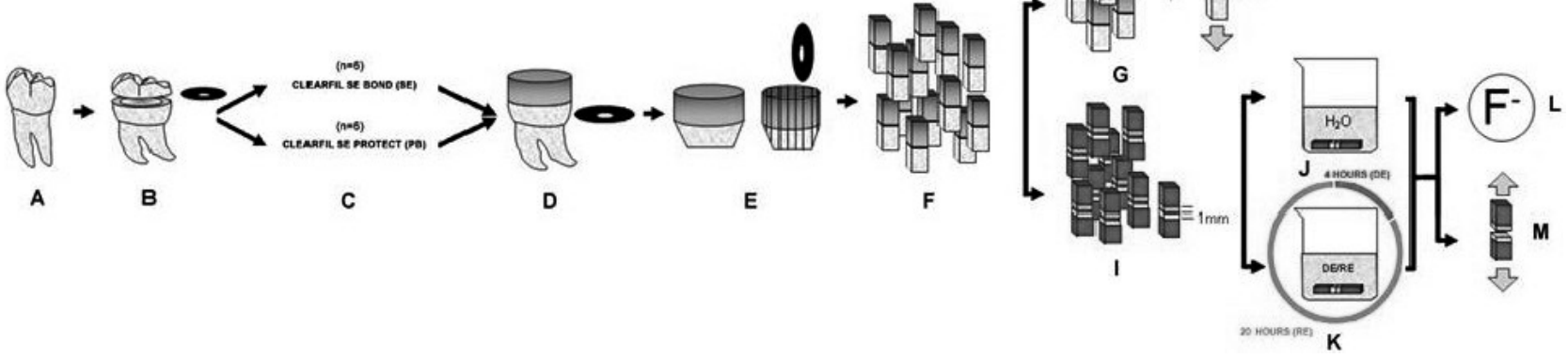

Figure 1. Experimental design. (A) Human molars. (B) Superficial exposed dentin. (C) Teeth were bonded with SE or PB. (D) Composite (6 mm thickness block) prepared on dentin. (E) The block was trimmed using a fine diamond disc. (F). Sticks from the same tooth for each adhesive system were randomly divided into 3 subgroups according to storage time regimen. (G/H) $\mu$ TBS immediate. (1) The sticks submitted to a pH-cycling model and 5 months water storage were coated with an acid-resistant nail varnish except for $1 \mathrm{~mm}$ around the bonded interface area of the composite/dentin. (J) Sticks were stored for 5 months in deionized water. $(\mathrm{K})$ The remaining sticks were submitted to a pH-cycling model. (L) Evaluation of fluoride concentration from the PB (with fluoride) from DE/RE solutions and deionized water (M) $\mu \mathrm{TBS}$ after 5 months water storage and pH-cycling. 
solution (13). The DE and RE solutions used in this study were the same as those described by Lobo et al. (17) and the exposed dental area used was established based on Shinkai et al. (18).

Each stick was fixed to the grips of a microtensile device with a cyanoacrylate adhesive (Zapit, Dental Ventures of America Inc., Corona, CA, USA) and the microtensile bond test was conducted in a universal testing machine (Instron Corp, Canton, MA, USA) at a crosshead speed of $0.5 \mathrm{~mm} /$ min until failure (Figs. $1 \mathrm{H}, 1 \mathrm{M}$ ). Microtensile bond strength was determined in $\mathrm{MPa}$, which was derived by dividing the applied force $(\mathrm{kgF})$ at fracture by the bonding area $\left(\mathrm{mm}^{2}\right)$.

Data obtained from microtensile bond strength (MPa) were submitted to split plot two-way ANOVA (adhesive systems and storage time regimen) after observing the normal distribution of data and homoscedasticity of the variances. It was considered as factorial scheme the adhesive systems as parcel, and the storage time model and the interactions between the factors as sub-parcels. Multiple comparisons were performed using the Tukey's test (SigmaStat, version 3.5.0.54, Systat Software Inc) $(p<0.05)$.

The fractured specimens were mounted on coded brass stubs, gold coated with a sputter coater (BalzersSCD 050, Balzers Union AG, Liechtenstein) and examined using scanning electron microscopy (JSM 5600 LV, Jeol, Tokyo, Japan). The mode of failure was classified as follows: cohesive within composite (CC), cohesive within dentin $(C D)$, adhesive $(A)$ and mixed $(M)$, involving composite, dentin and adhesive.

As a confirming outcome, fluoride release from fluoride-containing adhesive system was measured from all storage solutions. Fluoride concentration in DE/RE solutions and deionized water (Fig. 1L) was obtained by collecting $0.5 \mathrm{~mL}$ of these solutions and adding 0.05 $\mathrm{mL}$ of TISAB III, from 1 to 4 days (DE, RE and deionized water) and 30 days (deionized water). Sample readings were captured in millivolts $(\mathrm{mV})$ and transformed into $\mu \mathrm{gF}-/ \mathrm{mL}$ (ppm F-) by linear regression of the calibration curve (of $0.01562 ; 0.03125 ; 0.0625 ; 0.125 ; 0.25$ and 0.5 ppm F). Baseline fluoride measurements of the DE-RE solutions were obtained prior to the $\mathrm{pH}$-cycling process or water storage. It was considered as fluoride released amount the fluoride concentration measured after the $\mathrm{pH}$-cycling process minus the one measured at baseline. The same was done for deionized water. Fluoride release was detected using a fluoride-specific electrode connected to a microprocessor ion analyzer (Orion EA-940, Orion Research Inc., Boston, MA 02129).

Standard solutions were prepared from sodium fluoride solution with concentrations of $0.01562 ; 0.03125 ; 0.0625$; $0.125 ; 0.25$ and 0.5 ppm F- to which TISAB III (Total Ionic Strength Adjustment Buffer, Termo Orion, Beverly, MA, USA) was added in order to obtain a constant background ionic strength and to evaluate fluoride release. Data were submitted to Friedman's non parametric test and non parametric multiple comparisons test with 5\% significance level.

\section{Results}

According to ANOVA in split plot design, there was no significant interaction between factors $(p=0.4265)$. The microtensile bond strength ( $\mu \mathrm{TBS}$ ) results are shown in Table 1. The statistical analysis showed no statistically significant differences between the adhesive systems

Table 1. Means (SD) for microtensile bond strength (MPa).

\begin{tabular}{|c|c|c|c|}
\hline \multirow{2}{*}{ Storage time regimen } & \multicolumn{3}{|c|}{ Adhesive Systems } \\
\hline & Clearfil SE Protect (PB) & Clearfil SE Bond (SE) & Mean \\
\hline Immediate - control & $30.5(3.7)$ & $28.6(1.5)$ & $29.6(2.3) \mathrm{a}$ \\
\hline pH-cycling model & $31.2(8.2)$ & $27.5(4.5)$ & $29.4(6.6) \mathrm{a}$ \\
\hline 5 months water storage & $27.3(6.9)$ & $20.6(3.0)$ & $24.0(6.1) \mathrm{b}$ \\
\hline Mean & $29.7(6.4) \mathrm{A}$ & $25.6(4.7) \mathrm{A}$ & \\
\hline
\end{tabular}

Means followed by different uppercase letters in the same row and lowercase letters in the same column indicate statistically significant difference $(p<0.05)$. There was no significant interaction ( $>0.05)$ between studied factors (adhesive systems $x$ storage time regimen). 
Clearfil SE Protect (PB) and Clearfil SE Bond (SE) ( $p=0.0811)$. The immediate - control group and $\mathrm{pH}$-cycling model groups resulted in $\mu$ TBS significantly higher than the 5-month water storage group. No significant differences were found between the immediate - control group and the $\mathrm{pH}$-cycling model ( $\mathrm{p}>0.05)$.

The results for failure mode distribution are shown in Table 2. A predominance of cohesive failure within composite was observed for the groups immediate -

Table 2. Frequency distributions of the failure modes of the tested groups (\%).

\begin{tabular}{|c|c|c|c|c|c|}
\hline \multirow{2}{*}{ Storage time regimen } & \multirow{2}{*}{$\begin{array}{l}\text { Adhesive } \\
\text { Systems }\end{array}$} & \multicolumn{4}{|c|}{ Failure Modes (\%) } \\
\hline & & $\mathrm{CC}^{*}$ & $C D^{*}$ & $A^{*}$ & $\mathrm{M}^{*}$ \\
\hline \multirow{3}{*}{ Immediate - control } & PB & 48 & 4 & 24 & 24 \\
\hline & & & & & \\
\hline & SE & 40 & -- & 28 & 32 \\
\hline \multirow{3}{*}{ pH-cycling model } & PB & 44 & - & 16 & 40 \\
\hline & & & & & \\
\hline & SE & 28 & 12 & 12 & 48 \\
\hline \multirow{2}{*}{$\begin{array}{l}\text { 5-month water } \\
\text { storage }\end{array}$} & PB & 28 & 4 & 36 & 32 \\
\hline & SE & 16 & -- & 40 & 44 \\
\hline
\end{tabular}

CC: Cohesive within composite; $\mathrm{CD}$ : Cohesive within in dentin; A: adhesive; and M: mixed, involving composite, dentin, and adhesive. PB: Clearfil SE Protect and SE: Clearfil SE Bond.

Table 3. Amount of fluoride released (ppm F-) from the Clearfil SE Protect (PB) adhesive system in the DE/RE solutions, relative to baseline.

\begin{tabular}{lccc}
\hline Day & Median & Minimun value & Maximum value \\
\hline $1 \mathrm{DE}$ & $0.01 \mathrm{a}$ & 0.01 & 0.03 \\
$2 \mathrm{DE}$ & $0.01 \mathrm{a}$ & 0.01 & 0.02 \\
$3 \mathrm{DE}$ & $0.01 \mathrm{a}$ & 0.01 & 0.02 \\
$4 \mathrm{DE}$ & $0.01 \mathrm{a}$ & 0.01 & 0.02 \\
$1 \mathrm{RE}$ & $0.005 \mathrm{ab}$ & 0 & 0.01 \\
$2 \mathrm{RE}$ & $0 \mathrm{ab}$ & 0 & 0.01 \\
$3 \mathrm{RE}$ & $0 \mathrm{~b}$ & 0 & 0 \\
$4 \mathrm{RE}$ & $0 \mathrm{~b}$ & 0 & 0 \\
\hline
\end{tabular}

Means followed by different lowercase letters in the each column differ significantly at 5\% according to the Friedman's test. control. For the $\mathrm{pH}$-cycling model group the predominance of mixed failures was observed. However, for the 5-month water storage group the predominant failure mode was adhesive for PB and mixed for SE.

Fluoride release for the Clearfil SE Protect adhesive system was below the minimum concentration of the calibration curve $(0.03125 \mathrm{ppm} F)$. The minimum and maximum fluoride release values in the DE solution were 0.01 and $0.03125 \mathrm{ppm} F$, and for RE solution, 0 and 0.01 ppm F (Table 3). There was no fluoride release from Clearfil SE Protect when stored in deionized water in all periods of time. Similar results were observed for Clearfil SE Bond.

\section{Discussion}

Composite resin is the preferred material for conservative direct restorations. Fluoride has been incorporated in some composite and adhesive systems with the expectation of inhibiting secondary caries lesions (2-4) and even stabilizing or improving the long-term bond strength $(2,3,14-16)$.

In this study, the first hypothesis was accepted. No statistical difference in the $\mu$ TBS was found between the adhesive system with fluoride (Clearfil SE Protect) and the system without fluoride (Clearfil SE Bond), irrespective of the storage regimen (Table 1). These results are similar to those reported by Imazato et al. (15) and Shinohara et al. (3) where MDPB incorporation into the dentin primer and sodium fluoride into adhesive systems showed no adverse effect on $\mu$ TBS or on polymerization after $24 \mathrm{~h}$.

Although there was no significant difference in $\mu$ TBS between the two adhesive systems, more degradation was observed around Clearfil SE Bond specimens subjected to $\mathrm{pH}$-cycling (Fig. 2). This degradation may have caused the higher incidence (48\%) of mixed mode failures compared to the adhesive system with fluoride (40\%) (Table 2). Despite the low F- ion release, the Clearfil SE Protect adhesive system seems to have a protective influence on the dentin/adhesive system bond because most specimens did not show degradation in the $\mathrm{pH}$-cycling model.

Other studies have shown the ability of fluoride-releasing adhesive systems to inhibit secondary caries development and prevent dentin degradation, resulting in stability of the adhesive 
interface (2-4,14-16). This study found low F- ion release in the DE/RE solution (Table 3 ) and no F- ion release in deionized water (Table 4). A possible explanation may be the form in which fluoride is released from composite or adhesive systems, which is known to depend on the $\mathrm{pH}$ and storage environment $(6,8,19)$. Note that a higher fluoride release was found in the $\mathrm{DE}$ solution $(\mathrm{pH}=4.3)$. Fluoride in the material could also be immobilized by the polymeric matrix, preventing its release (20). Moreover, the low fluoride concentration released from the adhesive system may have been related to the portion exposed to the solutions, which was only at the dentin/composite interface.

The second hypothesis tested was partially accepted. The present study found significant differences in $\mu$ TBS between immediate - control and the 5- month storage regimens, but $\mu$ TBS did not decrease significantly after the pH-cycling (Table 1). Peris et al. (13) reported a significant decrease in bond strength after $\mathrm{pH}$-cycling. A difference to their study is that they used bovine instead of human teeth.

The result that the bond strength was not significantly affected by the $\mathrm{pH}$-cycling may be attributed to the formation of inhibition zones in the dentin adjacent to the bond interface. This "acid-resistant zone", that resists acid etching during the $\mathrm{pH}$-cycling model (14), was observed when the adhesive system contained fluoride (3).

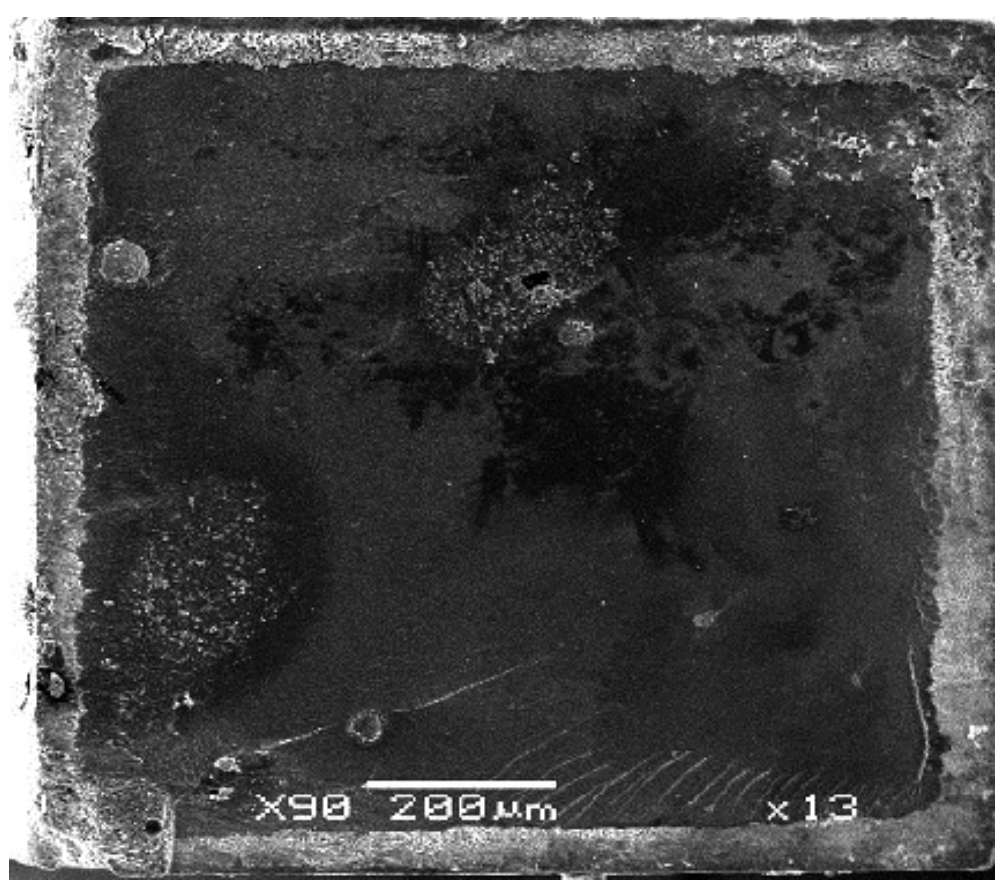

Figure 2. SEM of the dentin/bonding agent/composite interface after fracture for an adhesive system without fluoride (Clearfil SE Bond), showing demineralization around the bond area in the $\mathrm{pH}$-cycling model.
However, in no-fluoride adhesive systems it is less evident. Probably, the acid-resistant zone was able to maintain the similarity of the bond strength for the two adhesive systems. Although the difference in bond strength was not significant, there was evidence that demineralization around the bond area in the $\mathrm{pH}$-cycling model weakened the dentin, resulting in a higher incidence of mixed mode failure compared to the other test regimens (Table 2).

The durability challenge of the bond became evident after the specimens were stored in deionized water for 5 months (Table 1). The outcome of the current study confirms degradation results previously reported at the resin/dentin interface after long-term storage in water $(11,12)$. This bond strength reduction has been attributed mainly to hydrolytic degradation of the adhesive and collagen fibers (21). Unlike the results of the current study, Nakajima et al. (2) and Donmez et al. (16) reported that 6 months to 1 year of storage in water did not reduce the bond strength of an adhesive with fluoride (Clearfil SE Protect), while Clearfil SE Bond (without fluoride) decreased. Note that Donmez et al. (16) used a thin layer of resin composite liner (Protect Liner F) which may have increased the amount of fluoride in the environment. The absence or very low release of fluoride in the present study may thus have led to the similar results for both adhesives.

Water absorption within resin-tooth interfaces is another mechanism involved in bond degradation and marginal quality (22). Both adhesives tested in this study showed reduced bond strength after 5 months of water storage. Water molecules may diffuse through the material and bind to hydrophilic groups or water molecules may diffuse through pores or micromorphological defects without mutual relationship to the polar sites in the material (23). Hydrophobic adhesive systems tend to take up lower quantities of water and consequently present a lower hydrolytic degradation rate (22). In addition to the degree of hydrophilicity, factors such as the degree of conversion, quantity of cross-linking and solubility in water affect the mechanical behavior of current adhesive systems exposed to water for extended periods of time (24).

In this study, the fluoride released in the adhesive system did not change the 
bond strength performance in comparison to the adhesive system when it did not contain fluoride. The type of used substrate (human tooth), $\mathrm{pH}$-cycling model and the specimen dimensions (amount of fluoride release) may all have influenced the results, and should be investigated further in future research. Although it should be acknowledged that in vitro models cannot account for all processes and quantities that may contribute to clinical long-term bonding performance (25). In vitro models as water exposure and $\mathrm{pH}$-cycling are essential to obtain basic insight into select factors that may play a role in the bond degradation process.

Within the limitations of the present in vitro study, it can be concluded that the fluoride-containing adhesive systems did not influence the $\mu$ TBS. Five months water storage showed higher degradation of $\mu$ TBS values of the fluoride and non-fluoride adhesive systems than those observed immediately and after $\mathrm{pH}$ cycling model. Failure mode was dependent on storage model and adhesive system. The fluoride-containing adhesive system released fluoride ions only into the DE/RE solutions. A fluoridecontaining adhesive system showed similar performance as a non fluoride-containing adhesive system in an in vitro simulation of a high caries activity patient.

\section{Acknowledgements}

This study was supported by the funding agency CAPES.

\section{Resumo}

0 objetivo principal desse estudo foi avaliar a resistência de união à microtração de dois sistemas adesivos (com e sem flúor) após a ciclagem de $\mathrm{pH}$ e armazenagem em água deionizada. A quantidade de flúor liberada foi avaliada secundariamente. Doze terceiros molares hígidos foram separados em 2 grupos de acordo com o sistema adesivo: Clearfil SE Protect - com flúor (PB) e Clearfil SE Bond - sem flúor (SE). Os palitos $\left(1 \mathrm{~mm}^{2}\right)$ obtidos do mesmo dente foram aleatoriamente divididos em 3 subgrupos de acordo com o meio de armazenagem: em água deionizada por $24 \mathrm{~h}$ ou 5 meses e ciclagem de $\mathrm{pH}$. Os palitos foram tracionados em uma máquina de ensaio universal a $0,5 \mathrm{~mm} /$ $\min$. A concentração de flúor foi analisada em água deionizada (1-4 dias e 30 dias) e na solução remineralizadora e desmineralizadora (1-4 dias) usando um eletrodo específico. Os dados de resistência de união e liberação de flúor foram, respectivamente, submetidos à Análise de Variância em esquema de parcela subdividida e ao teste de Friedman $(\alpha=0,05)$. Não houve nenhuma interação significativa na resistência de união entre os sistemas adesivos e os meios de armazenagem. Os menores valores de resistência de união à microtração foram encontrados para os palitos armazenados em água deionizada. Não houve nenhuma diferença significativa nos valores de resistência de união após $24 \mathrm{~h}$ e ciclagem de $\mathrm{pH}$. Nenhuma diferença significativa na resistência de união foi observada entre os 2 sistemas adesivos. 0 modo de falha foi predominantemente coesivo em compósito para os grupos armazenados em água por 24h ou 5 meses para ambos os sistemas adesivos. No grupo submetido à ciclagem, a falha foi mista para o SE e coesiva em compósito para o PB. A concentração de flúor nas soluções $D E / R E$ foi menor que 0,03125 ppm e não detectada em água deionizada. Concluindo, o sistema adesivo com flúor (PB) apresentou performance similar ao sistema adesivo sem flúor (SE). A degradação hidrolitica foi o principal fator para ambos os sistemas adesivos, independente da adição de flúor.

\section{References}

1. Hara AT, Queiroz CS, Freitas PM, Giannini M, Serra MC, Cury JA. Fluoride release and secondary caries inhibition by adhesive systems on root dentine. Eur J Oral Sci 2005;113:245-250.

2. Nakajima M, Okuda M, Ogata M, Pereira PNR, Tagami J, Pashley DH. The durability of a fluoride-releasing resin adhesive system to dentin. Oper Dent 2003;28:186-192.

3. Shinohara MS, Yamauti M, Inoue G, Nikaido T, Tagami J, Giannini M, et al.. Evaluation of antibacterial and fluoride-releasing adhesive system on dentin--microtensile bond strength and acid-base challenge. Dent Mater J 2006;25:545-552.

4. Nikaido T, Ichikawa C, Li N, Takagaki T, Sadr A, Yoshida Y, et al.. Effect of functional monomers in all-in-one adhesive systems of formation of enamel/dentin acid-base resistent zone. Dent Mater J 2011;30:576582.

5. dos Santos RL, Pithon MM, Vaitsman DS, Araujo MT, de Souza MM, Nojima MG. Long-term fluoride release from resin-reinforced orthodontic cements following recharge with fluoride solution. Braz Dent J 2010;21:98-103.

6. Passalini P, Fidalgo TK, Caldeira EM, Gleiser R, Nojima M da C, Maia LC. Preventive effect of fluoridated orthodontic resins subjected to high cariogenic challenges. Braz Dent J 2010;21:211-215.

7. Basso GR, Della Bona A, Gobbi DL, Cecchetti D. Fluoride release from restorative materials. Braz Dent J 2011;22:355-358.

8. Paschoal MA, Gurgel CV, Rios D, Magalhaes AC, Buzalaf MA, Machado $M A$. Fluoride release profile of a nanofilled resin-modified glass ionomer cement. Braz Dent J 2011;22:275-279.

9. Basso GR, Borba M, Bona AD. Influence of different mechanisms of fluoride release from adhesive systems. Braz Dent J. 2013;24:522-526.

10. da Silva BM, França FM, Flório FM, Basting RT. In situ anticariogenic effect of adhesive systems containing fluoride and MDPB. Am J Dent 2010;23:75-80.

11. Armstrong SR, Vargas MA, Fang 0 , Laffoon JE. Microtensile bond strength of a total-etch 3-step, total-etch 2-step, self-etch 2-step, and a self-etch 1-step dentin bonding system through 15-month water storage. J Adhes Dent 2003;5:47-56.

12. de Munck J, Van Meerbeek B, Yoshida Y, Inoue S, Vargas M, Suzuki K, et al.. Four-year water degradation of total-etch adhesives bonded to dentin. J Dent Res 2003;82:136-140.

13. Peris AR, Mitsui FHO, Lobo MM, Bedran-Russo AKB, Marchi GM. Adhesive systems and secondary caries formation: Assessment of dentin bond strength, caries lesions depth and fluoride release. Dent Mater 2007;23:308-316.

14. Itota $T$, Nakabo S, Iwai $Y$, Konishi N, Nagamine M, Torii Y. Inhibition of artificial secondary caries by fluoride-releasing adhesives on root dentin. J Oral Rehabil 2002;29:523-527.

15. Imazato S, Kinomoto $Y$, Tarumi H, Ebisu S, Tay FR. Antibacterial activity and bonding characteristics of an adhesive resin containing antibacterial monomer MDPB. Dent Mater 2003;19:313-319.

16. Donmez N, Belli S, Pashley DH, Tay FR. Ultrastructural correlates of in vivo/in vitro bond degradation in self-etch adhesives. J Dent Res 2005;84:355-359.

17. Lobo MM, Gonçalves RB, Pimenta LAF, Bedran-Russo AKB, Pereira 
PNR. In vitro evaluation of caries inhibition promoted by self-etching adhesive systems containing antibacterial agents. J Biomed Mater Res B Appl Biomater 2005;75:122-127.

18. Shinkai RS, Cury AA, Cury JA. In vitro evaluation of secondary caries development in enamel and root dentin around luted metallic restoration. Oper Dent 2001;26:52-59.

19. Carvalho AS, Cury JA. Fluoride release from some dental materials in different solutions. Oper Dent 1999;24:14-19.

20. Toba S, Pereira PNR, Nikaido T, Medical T, Hill C. Effect of topical application of fluoride gel on artificial secondary caries inhibition. Int Chin J Dent 2003;3:53-61.

21. Burrow MF, Satoh M, Tagami J. Dentin bond durability after three years using a dentin bonding agent with and without priming. Dent Mater 1996;12:302-307.

22. Reis AF, Carrilho MRO, Ghaname E, Pereira PNR, Giannini M, Nikaido T, et al.. Effects of water-storage on the physical and ultramorphological features of adhesives and primer/adhesive mixtures. Dent Mater J 2010;29:697-705.

23. Morel $E$, Bellenger $V$, Bocquet $M$, Verdu J. Structure-properties relationships for densely cross-linked epoxide-amine systems based on epoxide or amine mixtures. J Mater Sci 1989;24:69-75.

24. Ferracane JL, Berge HX, Condon JR. In vitro aging of dental composites in water-effect of degree of conversion, filler volume, and filler/matrix coupling. J Biomed Mater Res 1998;42:465-472.

25. White DJ. The application of in vitro models to research on demineralization and remineralization of the teeth. Adv Dent Res 1995;9:175-193.

Received January 28, 2014 Accepted August 18, 2014 